\title{
The Recent Development in Commodity Flow Analysis
}

\author{
Setsuko MitsuHASHI \\ 三 橋 節 子
}

In the commercial world, a real specialization produces comparative advantages, in which each region produces those goods and services which it can most economically produce, relative to alternative types of production and alternative sources and markets (Mayer 1963). The Law of Comparative Advantage operates because of transportation, and gives rise to traffic flows between regions of specialized production and regions of consumption, which Ullman $(1956,1957)$ calls "complementarity". Consequently, complementarity is a function of areal differentiation promoting spatial interaction. Movement takes place between unlike regions, producing "place utility", whereby goods and services are consumed where the demand for them exist regardless of the location of the source. Traffic flows are subject to "intervening opportunities" of competitive sources and markets, and to "transferability" (Ullman 1956, 1957) or distance. That is, complementarity generates interchange between two areas only if intervening complementary soruce of supply is not available. And, if the distance between market and supply was too great and too costly to overcome, interaction would not take place in spite of perfect complementarity and lack of intervening opportunity. The factor of intervening opportunity results in a substitution of areas, and the factor of transferability or distance results in a substitution of products. Distance and intervening opportunity drastically trim down the relative quantity of these long-distance relationships.

Gould and Smith, using regression, analyzed Ghananian and Australian commodity flows whether they move more or fewer than expected on the basis of their population (Gould and Smith 1961; Gould 1960; Smith 1962, 1963a, b). Gould obtained strong relationships between rail shipments from Takoradi, Ghana and the population of the receiving station, and Smith between rail shipments from Sydney and Melbourne to southern New South Wales and the population of receiving towns. Smith explained the variation from regression equation must be due to road transprot competition from Melbourne, and, to a lesser extent, from Sydney. Distance is also important in predicting commodity flows. Gould observed a systematic decline in the volume of goods as distance increased, and Smith obtained a similar relationship between receipts per capita from two major origins at a set of southern New South Wales towns and distance from these origins. Smith (1964) developed the measurement of complementarity, using complementarity index, comparing the actual flow with the expected volume. The method used only one variable derived from a modified form of the gravity model of interaction. That is, for the analysis of agricultural commodity flow to New England, attractive forces are agricultural surplus of each shipping state and populations of receiving states, and the friction is represented by airline distance. The result of calculation was weighted by the 
proportion of imports to New England that each shipment represents, in order to emphasize strong trade relations. For the analysis, the gravity model combined with regression analysis was adapted, in order to judge whether states sent more or fewer tons of agricultural goods than might be expected.

Morrill and Garrison (1960) projected interregional trade patterns in wheat and flour in the U.S., using a spatial price equilibrium model. That is, increases in domestic wheat price, time or average hourly wages, have depressing effects upon wheat consumption, while rising per captia income has a positive effect. While the demand for wheat for flour was measured by flour mill capacitiy, the demand for flour was measured by regional population. And the resulting equation for flour consumption was similar to that for wheat. Once formulated, the model can be used to test the effects of changes in internal regional condition or external transportation connections, such as the effect of a supply change resulting from a drought, or the effect of changes in the distribution of population among regions. Concerning state to state commodity flows in the U.S., Spiegelglas (1960) calculated rank order correlation to examine the relationship between trade of each state and its level of economic activity and its relative role in the national economy. If all the states are ranked according to their sum totals of their exports and imports, such a ranking order is highly correlated with the size of the state population, the value added by manufacture, or personal income.

Boxer (1961) sought to develop generalizations about the structure of flow patterns in Hong Kong. The structure of shipping into and out of the port of Hong Kong were analyzed, and 37 characteristics were identified. The 37 by 37 correlation matrix revealed a number of structural attributes of Hong Kong's overseas shipping. Helvig (1964) analyzed a functional relationship between number of Chicago's external truck trips and its structure and magnitude, and distance between origins and destinations by regression analysis. In this analysis, the gravity model functioned well, provided the areal units were not too small, and he found four hinterland levels in Chicago's external truck movements. Using the market potential for grouping relative location in the U.S., Pred (1964) could generalize with respect to the volume and length of all manufacturing commodity flows that have high, intermediate and low market accessibility. The distinction in flow characteristics can be refined by consideration of three fundamental industry types, in terms of cost and location factors - raw material and power oriented, market oriented, and localization by labor and agglomeration economies. Market oriented industry flows are restricted areally, because their ability to absorb transportation costs is less than that of higher-value-added industries localized by labor or agglomeration economies. The higher the value added, the greater the distance of shipment than can be tolerated. Ray (1965) also explained the spatial variations in the amount of manufacturing activity in southern Ontario by dual interactions, comprising market potential and economic shadow. Market potential is a region's accessibility to markets by means of a simple interactance model, and it explained statistically $3 / 4$ of the spatial variation in manufacturing activity in southern Ontario. Economic shadow is a region's inability to supplement locally-owned industry with branch plants controlled from outside the main market area, 
and comprises three elements - interactance decay, sectoral affinity and sectoral penetration. Economic development beyond the primary regional market centers is hindered by the economic shadow resulting from the action of these primary urban centers as intervening opportunities.

Using graph theory, Kansky (1963) dealt with the relationship between the structure of transportation networks and regional characteristics. The railway networks of twentyfive countries were related to their general level of economic development. Energy consumption was plotted against a measure of connectivity, and gross national product per captia was plotted against a measure of network shape. These trends were statistically significant, and this suggested that the geometry of route networks may be closely related to the development of the region. A simulation model was developed for connecting the population nodes of Sicily by a railroad network. The basis of the simulation was to predict the probable localization of railway routes from the geographic characteristics of the area, such as size of Sicily, variability of physical relief, and shape of the island. The number of railroad routes, their average length, and rate of extension of the routes may either be derived from the historical evidence or predicted from comparative studies of railway parameters in terms of an area's general level of economic development. This model was a reliable method for forecasting the complex spatial structure of transportation networks. Perle (1964) examined the demand for freight transportation in the U.S. as exemplified by motor carrier and railroad behavior. Transport demand was analyzed for all commodities in the U.S. and by major commodity groups, then the total regional demand, and individual region and commodity combinations. There were persistent increases in motor carrier tonnages and decreases in railroad tonnages, though the magnitude of changes is quite variable depending on commodity groups. Transport demands by region yielded elastic responses in the New England, Midwestern, Rocky Mountain and Pacific Regions. Appreciable inelasticity is associated with rather large growth rates, as in the Southern, Middle Atlantic and Northwestern Regions, and mild inelasticity in the Central and Southwestern Regions.

Berry (1966) used factor analysis in his Indian commodity flows between thirty-six trade blocks. In R-mode analysis, factor loadings yield groups of destinations (consuming regions), and factor scores indicate the sources of shipments to each group. In Q-mode analysis, factoring yields groups of origins (producing regions) and destinations of shipments from each group. The factoring process is essentially taxonomic when applied to commodity flow patterns. It explores similarities in flow pattern, groups origins and destinations into functional regions on the basis of their similarities, and reveals the basic anatomy or the flows. However, the process does not reveal directly the distance-decay functions, nor a predictive model of flows. In general field theory of spatial structure and spatial behavior, Berry (1968a, b) used a spatial system that comprises places, the attributes of these places, and the interactions between places, through time. Factoring an $n$-place by a-attribute matrix, yields an $n$ by $\mathrm{s}$ structure matrix, including independent basic concepts such as economic development and traditional centrality. Similarly, an $\left(n^{2}-n\right)$ by $y$ interaction matrix can be built including commodity flows of different kinds, 
where the $\left(\mathrm{n}^{2}-\mathrm{n}\right)$ paris of places (dyads) are treated as individual observations. This matrix can be reduced to an $\left(n^{2}-n\right)$ by $b$ behaviour matrix by factor analysis, indexing independent basic concepts such as complementarity, intervening opportunity and distance decay. This matrix summarizes the basic types of spatial interaction and their patterns of areal functional or organization. Reed (1967) found commodity exchanges of the BengalBihar Industrial Area vary inversely with distance shipped and directly with demand or supply conditions throughout India. The potential model summarizing this relationship was appropriate for analyzing both inflows and outflows of the area and accounted for over $50 \%$ of the variation in the volume of individual and total commodity flows. The potential model was modified by substituting an intervening opportunity and a competition variable in place of distance. The measure of intervening opportunity was closely correlated with distance, while competition, as measured by supply or demand potential at points outside the study area, had minimal correlation with the flows. Modified model, however, did not provide increased explanation. To explain flow patterns, Reed drew on Linnemann's econometric model of international trade flows, using gross national products, population, distance, preferential trade factor and commodity composition variable, as Berry (1966) did in his Indian commodity flow analysis.

By the factor analysis of inter-district telephone calls, Illeris and Pedersen (1968) analyzed central places and functional regions in Denmark. Because of the distance dependency in most communication matrices, the first factor explains a large part of the origination fields of all the districts around the biggest city. The second factor represents a big town located at some distance from the biggest one, because the origination fields of the towns close to the biggest one have already been explained by the first factor. The centers resulting from the factor analysis are spaced far apart, each dominating its own hinterland, but located outside the influence fields of other centers. Regional centers pointed out according to these principles will be the appropriate ones for the location of regional activities.

In the seventh issue of The East Lake Geographer on Transportation Geography, the spatial and behavioral aspects of the research based upon methodological techniques were sought. Britton (1971) tried to establish the existence of a methodology of flow analysis. He used three stages on the grounds of the nature of the data used in analysis: raw tonnage data on inter- regional flows in Stage 1, flows standardized for economic size of origins and destinations in Stage 2, and a further set of standardized flows in terms of interactance model in Stage 3. He concluded that the use of factor analysis to describe patterns of interregional connection is successful. The order perceived is associated with the variables normally associated with the model used to estimate the relationship in a spatial flow system.

Chisholm and O'Sullivan (1973), in estimating the generation of traffic, regressed the total British freight tonnage on the three independent variables of resident population, employed population and retail turnover. Despite the non-significance of results for rail freight, the regressions for road plus rail account for a high proportion of the variance in the dependent variables - resident population and employment, while for road alone the 
performance is rather better. Retail turnover proved to perform less well as a measure of demand. However, the three gross variables proved inadequate for prediction of the volumes of the individual commodity groups. The gravity model, applied to aggregate road freight flows, yielded high explanation, which is about the same as the level attained in estimating volumes generated and attracted, using the gross variables of population and employment. Disaggregated to commodities, the gravity model performed less well. Linear programming solutions for the commodities provided a better fit, though not sufficiently good to make confident predictions.

This paper is dedicated to Professor Noh on his retirement.

(1975. 2. 18 受理)

\section{References}

Berry, B.J.L. (1966): Essays on Commodity Flows and the Spatial Structure of the Indian Economy Univ. of Chicago Dept. of Geogr. Res. Paper 111

(1968a): Interdependency of Spatial Structure and Spatial Behavior: a General Field Theory Formulation Papers and Proc. Region. Sci. Ass. 21 205 227

(1968b): A Synthesis of Formal and Functional Regions Using a General Field Theory of Spatial Behavior Spatial Analysis - A Reader in Statistical Geography, ed. by B.J.L. Berry and D.F. Marble, Englewood Cliffs: Prentice-Hall 419 248

Boxer, B. (1961): Ocean Shipping in the Evolution of Hong Kong Univ. of Chicago Dept. of Geogr. Res. Paper $\mathbf{7 2}$

Britton, J. (1971): Methodology in Flow Analysis East Lake Geogr. $722 \sim 36$

Chisholm and O'Sullivan (1973): Freight Flows and Spatial Aspects of the British Economy Cambridge Univ. Press

Gould, P.R. (1960): The Development of the Transportation Pattern in Ghana Northwestern Univ. Study in Geogr. 5

and R.H.T. Smith (1961): Method in Commodity Flow Studies Australian Geogr. 8 $73 \sim 77$

Helvig, M. (1964): Chicago's External Truck Movements: Spatial Interactions between the Chicago Area and its Hinterland Univ. of Chicago Dept. of Geogr. Res. Paper 90

Illeris, S. and P. Pedersen (1968): Central Places and Functional Regions in Denmark, Factor Analysis of Telephone Traffice Lund Studies in Geogr. Ser. B. 31

Kansky, K.J. (1963): Structure of Transportation Networks Univ. of Chicago Dept. of Geogr. Res Paper 84

Mayer, H. (1963): Urban Geography and Urban Transportation Planning Traffic Quaterly 17610 $\sim 631$

Morrill R.L. and W.L. Garrison (1960): Projections of Interregional Patterns of Trade in Wheat and Flour Econ. Geogr. 36 116 126

Perle, E. (1964): The Demand for Transprotation: Regional and Commodity Studies in the U.S. Univ. of Chicago Dept. of Geogr. Res. Paper 95

Pred, A. (1964): Toward a Typology of Manufacturing Flows Geogr. Rev. 54 65 84

Ray, D.M. (1965): Market Potential and Economic Shadow: a Quantitative Analysis of Industrial Location in Southern Ontario Univ. of Chicago Dept. of Geogr. Res. Paper 101

Reed, W.E. (1967): Areal Interaction in India: Commodity Flows of the Bengal-Bihar Industrial Area Univ. of Chicago Dept. of Geogr. Res Paper 110

Smith, R.H.T. (1962): Commodity Movements in Southern New South Wales Dept. of Geogr. Australian Nat. Univ.

(1963a): Transport Competition in Australian Border Areas: the Example of Southern New South Wales Econ. Geogr. $391 \sim 13$

(1963b): Railway Commodity Movements between New South Wales and Victoria: the 1960 Pre-Standardization Situation Australian Geogr. 9 88 96 
(1964): Toward a Measure of Complementarity Econ Geogr. $401 \sim 8$

Spiegelglas, S. (1960): Some Aspects of State-to-State Commodity Flows in the United States Jour. Region. Sci, 2 71 $\sim 80$

Ullman, E.L. (1956): The Role of Transportation and the Bases for Interaction Man's Role in Changing the Face of the Earth ed. by W.L. Thomas, Jr. Univ. of Chicago Press 862 880 (1957): American Commodity Flow Univ. of Washington Press 20 27

\section{物資流通分析の最近の発展}

\section{Setuko MitsUHASHI（三橋 節 子）}

Ullman は American Commodity Flow で物資の流勤を経济学の complimentarity，社会学の intervening opportunity と, 地理学の transferability とで説明した。一方に供給他方濡要がある場合, その 2 地域間に補足的 供給源がなければ, 補完性に上る2地域間の流通が起る。供給地と市場の輸送費がかさむ場合は, 補完性があり, intervening opportunity がなくとも，流通は起らない。Gould と Smith はガーナとオーストラリアの貨物流動を 人口で回帰分析した後, Smith はアメリカのニューイングランド地方への農作物の流動に gravity model を使って, complimentary index を考案した。アメリカ合衆国について, Morrill と Garrison は価格均衡モデルで小麦と小麦 粉の流動を説明し， Spiegelglas は州間の流動量を州人口，付加価值および 所得の順位相関で分析した。 potential model は, Pred がアメリカの工業製品の流動に, Ray がオンタリオ州南部の工業に, Reed がインドの BengalBihar 工業地域の貨物流動に適用した。回帰分析は Helving のシカゴのトラック輸送, Perle のアメリカ合衆国の貨 物輸送, 更に Chisholm と O'Sullivan のイギリスの貨物流動に用いられた。 Kansky は交通䌅と地域の経済発展と の関係をグラフ理論で説明した。因子分析は, Bery がインドの貨物輸送に, Britton はイギリスの貨物流動のトン数 を標準化して適用した。 